Historia i Polityka

Półrocznik poświęcony myśli politycznej i stosunkom międzynarodowym

Nr $9(16) / 201313-27$

DOI: http://dx.doi.org/10.12775/HiP.2013.001

Maria Pasztor (Uniwersytet Łódzki)

\title{
Granica na Odrze i Nysie Łużyckiej oraz plan Rapackiego jako problem bezpieczeństwa w Europie na przykładzie relacji polsko-włoskich w latach 1945-1959
}

\section{The border on the Oder and Neisse and the Rapacki Plan as a security problem in Europe on the example of Polish-Italian-relations 1945-1959}

Article takes up the problem of Polish-Italian relations after the World War II and the question the Polish western border in these relations. The assessment of Italian politicians on the recognition of the border on the Oder and Neisse have been shown in the text, as well as the importance of this process for the geopolitical situation in post-war Europe.

Background for the title issue was the question of the role and importance of Germany in the postwar order in Europe. Italian politicians had considered the German question as crucial for security in Europe and this dimension of foreign policy was superior for the Polish-Italian relations.

Słowa klucze: Maria Pasztor, granica na Odrze i Nysie, bezpieczeństwo w Europie, relacje polsko-włoskie

Uznanie Włoch za stronę walczącą przez zachodnich aliantów sprawiło, że rząd włoski od września 1944 roku zabiegał o udział w rozwiązaniu powojennych problemów Niemiec, domagając się uczestnictwa w pracach nad przygotowaniem traktatów pokojowych z tym krajem. Włosi żądali umiędzynarodowienia zagłębia Ruhry i dostaw węgla z tego obszaru, niezbędnego dla rozwoju ich przemysłu ciężkiego'. Ta ostatnia kwestia miała charakter priorytetowy, gdyż braków tego

1 P. Guillen, L'Italie et le problème allemand 1945-1955, Relations Internationales 1987, nr 51, s. 270. Rząd włoski domagał się umiędzynarodowienia zagłębia Ruhry od września 1945 r.; L. Berti, L'Italia e la Germania: L'atteggiamento della diplomazia italiana dal dopoguerra agli inizi degli anni '50, [w:] L'Italia e la politica di potenza in Europa (1950-60), red. E, di Nolfo, R. H. Rainero, B. Vigezzi, Milano 1992, s. 77. 
surowca nie mógł uzupełnić drogi węgiel amerykański ani fatalny pod względem gatunkowym węgiel z Polski, którego nieregularne dostawy utrudnione były z powodów komunikacyjnych i uzależnione od relacji politycznych z Warszawą. Zabiegi rządu włoskiego zmierzające do zaspokojenia zarówno materialnych jak i prestiżowych potrzeb Włochów wskutek negatywnej postawy ZSRR oraz Wielkiej Brytanii pozostały w tej mierze niespełnione ${ }^{2}$.

Tradycyjne, bliskie związki niemiecko-włoskie w połączeniu z ambicjami Rzymu pośredniczenia po wojnie w „rekoncyliacji” Niemców z Europą Zachodnią, sprawiły, iż włoska dyplomacja widziała swą szczególną rolę nie w budowie antyniemieckich aliansów lecz włączeniu zachodniej strefy okupacyjnej w tworzący się pod przewodnictwem USA system sojuszy. Już od połowy 1948 r. włoskie koła rządzące wypowiadały się za remilitaryzacją Niemiec i włączeniem ich zachodnich części do budowanego systemu bezpieczeństwa „wolnego świata”. We wrześniu 1950 r. włoski minister Spraw Zagranicznych, Carlo Sforza poparł na posiedzeniu Rady Atlantyckiej w Nowym Jorku amerykański plan zbrojenia Niemiec ${ }^{3}$. Postrzegały one interes Włoch w tym „aby linia walki z komunizmem została przesunięta jak najdalej na Wschód od Szczecina do Triestu” oddalając zagrożenie sowieckie od granic swego kraju ${ }^{4}$. W momencie powstania RFN prasa włoska związana kołami przemysłowymi na północy Włoch podkreślała, iż „to właśnie Niemcy są najlepszymi obrońcami kultury łacińskiej przed postępami słowiańskiego żywiołu"s. Dla większości kół politycznych tego kraju (poza komunistami i częścią lewego skrzydła socjalistów tj. Włoskiej Partii Socjalistycznej) powstanie „silnych, bogatych i dobrze uzbrojonych Niemiec” było synonimem uratowania Europy przed komunizmem ${ }^{6}$.

W tej sytuacji sprawa polskiej granicy zachodniej nie mogła liczyć na zrozumienie władz włoskich, której to kwestii nie poświęcały one większej uwagi. W latach 1945-1947, mając na względzie interesy polityczne Włoch, związane z kwestią Triestu (w tym udziału Polski w komisji polityczno terytorialnej do spraw Włoch na konferencji paryskiej), kolonii oraz toczące się rokowania handlowe

2 E. di Nolfo, La "politica di potenza" e le formule della politica di potenza. Il caso italiano (1952-1956), [w:] La politica estera italiana nel seconda dopoguerra 1953-1957, Milano 1993, s. 415-416; B. De Gasperi, Sforza, la diplomazia italiana e la politica di potenza dal trattato di pace al patto atlantico, [w:] L'Italia e la politica di potenza in Europa (1945-50), red. E, di Nolfo, R. H. Rainero, B. Vigezzi, Milano 1990, s. 6-8.

P. Guillen, op. cit., s. 282-283.

4 Documenti Diplomatici Italiani (dalej: DDI), serie XI, vol. I, dok. 449, P. Quaroni do L. Einaudi, Paryż 21 IX 1948.

5 Tempo di Milano 5 IX 1949. Cyt. za: P. Guillen, op. cit., s. 282.

6 P. Guillen, op. cit., s. 282. 
z Warszawą, dotyczące dostaw węgla, oficjalne czynniki włoskie unikały wypowiadania się na tematy związane z polską granicą zachodnią․ Podobne stanowisko w tej materii zajmowała włoska opinia publiczna, która jak donosił, jeszcze na początku 1947 r., ambasador Stanisław Kot, „była niechętna do zabierania głosu w sprawie granicy polsko-niemieckiej" ${ }^{3}$. Z trudności jakie napotykało propagowanie nad Tybrem polskiego stanu posiadania na tzw. Ziemiach Zachodnich oraz polskiej racji stanu odnośnie przebiegu granicy na Odrze i Nysie Łużyckiej, zdawała sobie doskonale sprawę, od samego początku, polska placówka w Rzymie. Ambasador Stanisław Kot podkreślał w swych doniesieniach do Warszawy, że „mimo klęski faszyzmu Włochy niewątpliwie będą ciążyć ku Niemcom”. Nakładało to na ambasadę, w jego przekonaniu, „bardzo poważne obowiązki: upartego, systematycznego, konsekwentnego - a przy tym dyskretnego wpływania na włoską opinię publiczną i politykę zagraniczną w duchu antyniemieckim, tak aby Włochy znalazły się w tym samym bloku co Polska”. Tak sformułowane zadanie przewyższało jednak realne możliwości nie tylko szczupłego personelu dyplomatycznego ale i polskiej polityki zagranicznej. Ambasada dysponowała zresztą bardzo skromnymi środkami budżetowymi, co poważnie ograniczało jej możliwości propagandowe. Za potrzebami nie nadążała ani akcja wydawania książek i broszur uzasadniających przesunięcie polskich granic w kierunku zachodnim ani tłumaczenie ich na język włoski. Ambasador Kot skarżył się na „nieodpowiednią dla realizacji zadań propagandowych, obsadę Biura Prasowego Ambasady RP” i podkreślał konieczność rozszerzenia współpracy na środowiska katolickie, „posiadające wpływ na stan włoskiej opinii publicznej”, co nie spotkało się z pozytywnym odzewem centrali. Mimo braku reakcji ze strony MSZ-u, Kot, na własną rękę podjął działania wychodzące po środowiska włoskiej lewicy, zwracając się m. in. do Macieja Loreta (uchodzącego w jego ocenie, za „najpoważniejszego członka kolonii polskiej w Rzymie”) z prośbą o propagowanie kwestii polskiej granicy zachodniej w środowiskach prawicy z którymi ambasada nie utrzymywała stosunków9

Zadanie propagowania polskiej granicy zachodniej wydawało się tym bardziej naglące, iż nawet wśród kręgów związanych z tzw. lewicą tj. Włoską Partią Socjalistyczną (WłPS) (a zwłaszcza jej prawym skrzydłem) „sytuacja problemu pol-

7 Archiwum Ministerstwa Spraw Zagranicznych w Warszawie (dalej: AMSZ), z. 6, t. 1247, w. 81, amb. S. Kot do MSZ w Warszawie. Podczas audiencji u min. Sz. De Gasperiego, tenże zapytał $\mathrm{m}$. in. Kota „czy liczymy na definitywne przyznanie nam granicy tymczasowej”. (...) Był zdumiony szczegółami o niszczeniu żywiołu polskiego przez Niemców, o tępieniu kultury polskiej, książek, rękopisów itp.”.

8 AMSZ, ZD, t. 104, w. 104, S. Kot do J. Cyrankiewicza, szyfr. nr 1643, Rzym 19 II 1947.

9 AMSZ, z. 15, t. 131, w. 14, S. Kot do MSZ, Zagadnienie polsko-niemieckie we Wtoszech, sprawozdanie nr 2, Rzym 11 I 1947. 
sko-niemieckiego”, jak pisał Kot, była „bardzo zła”. Tymczasem to właśnie z tych kręgów związanych z jej liderem Guiseppe Saragat'em mieli się, w jego trafnej ocenie, „wywodzić sympatycy odrodzenia Niemiec kosztem Polski”. Wśród tej części socjalistów częste były, według niego, „postawy współczucia wobec losu Niemców, którzy musieli opuścić obecne terytorium Polski oraz tych, którzy tam pozostali i byli krzywdzeni przez Polaków"10. Konieczność nawiązania szerszych kontaktów z politykami i działaczami prawicowej frakcji WłPS, cieszącymi się opinią „wpływowych” intelektualistów oraz „dobrych piór”, które miało spowodować odwrócenie proniemieckich sympatii wśród niektórych działaczy tej partii, skazane było jednak na niepowodzenie. Dodatkowo, szukanie stosunków z działaczami tego skrzydła narażało na szwank kontakty ze zwolennikami lewicowego skrzydła tej partii, Pietro Nenniego, zwolennika w tym czasie współpracy partii socjalistycznej z komunistami. W tych okolicznościach na niewiele zdały się próby polemiki podjęte z częścią proniemiecko nastawionych delegatów WłPS na kongresie tej partii we Florencji w 1946r. przez przedstawiciela CKW Polskiej Partii Socjalistycznej, Andrzeja Nowickiego ${ }^{11}$.

Ambasador Kot oraz polscy dyplomaci nad Tybrem zdawali sobie sprawę, iż jak to formułował Kot, „interes polsko-niemieckiej granicy wymaga zabiegów o paraliżowanie w tym obozie niechętnego nam stanowiska, zwłaszcza, że publicyści tego obozu mieli duży autorytet w opinii włoskiej poza socjalistycznej, zwłaszcza w kołach inteligencji radykalnej i w prasie”. Liczono przy tym, bezskutecznie, iż „nowa partia (Partito Socialista dei Lavoratori Italiani - PSLI) Giuseppe Saragata” (powołana na kongresie styczniowym WłPS w 1947 r. w Rzymie) „będzie się starała uchylić zarzut germanofilstwa i znajdziemy jakąś szczelinę, przez którą udałoby się wsunąć nasze oddziaływanie"12. Optymizm ambasadora okazał się jednak przesadzony, zwłaszcza, że Włosi nie byli skłonni do podejmowania tematu polskich granic, ani tym bardziej promowania rozwiązania tej kwestii zgodnie z interesami Warszawy.

10 Ibidem, Wystapienie posła Umberto Calosso z Turynu, który na Kongresie Wtoskiej Partii Socjalistycznej w 1946 r. zabrał głos na temat „tragicznego” losu Niemców na tzw. ziemiach odzyskanych przez Polskę.

11 Ibidem, polski delegat, A. Nowicki, petniacy jednocześnie funkcję kierownika referatu prasowego polskiego konsulatu w Mediolanie, zostat demonstracyjnie zagtuszony, a obecni na sali socjaliści zarzucili mu nacjonalizm.

12 AMSZ, z. 6, t. 1253, w. 82, S. Kot do ministra Spraw Zagranicznych [W. Rzymowskiego], W związu z problemem niemieckim, Rzym 16 I 1947. Wydaje się, że większego odgłosu nie miało przemówienie A. Nowickiego, kierownika referatu prasowego polskiego konsulatu w Mediolanie, na kongresie WłPS, które ambasada wydrukowała i rozdała uczestnikom Kongresu; AMSZ, z. 15, t. 131, w. 14, S. Kot do MSZ, Zagadnienie polsko-niemieckie we Wtoszech, sprawozdanie nr 2, Rzym 11 I 1947 . 
Prasa włoska, bowiem, w pierwszych latach powojennych - jak donosił ambasador Kot - „milczała w sprawie granicy polsko-niemieckiej. Pierwszy milczenie w tej sprawie przerwał dziennik rzymski „Il Quotidiano”, naczelny organ związanej z chadecją Akcji Katolickiej. Zamieścił on, na początku 1947 r., artykuł Emilio Buffo pt. „Kwestia polska”, poddający w wątpliwość przyznanie Polsce terytoriów nad Odrą i Nysa Łużycką. „Jeśli można się zgodzić, pisał autor, że istotnie linia Curzona stanowi najsprawiedliwsze granice, ze względu na zasadę narodowości, nie można nie być sceptycznym co do przyznawania Polsce terytoriów czysto niemieckich z kultury i rasy, które odrzuca sam rząd londyński”"13.

Wątpliwości względem decyzji zapadłych w Poczdamie co do przyznania Polsce wskazanych wyżej terenów wyrażali również w swych raportach niektórzy włoscy dyplomaci, podkreślając, iż zaistniałe zmiany terytorialne są przede wszystkim instrumentem polityki Moskwy w tej części Europy, a „popychając Polskę nad Odrę, ZSRR związał ją w sposób trwały ze swym rydwanem”. Przyznawali jednak, iż mimo polityka polskich komunistów ma swe „nieprzyjemne strony” („lati sgradevoli”) dla wielu Polaków, jakim jest konieczność rezygnacji z pomocy Zachodu czy zależność gospodarcza od Rosji, to jest ona dla Polski ,jedyną gwarancją" posiadania tych terenów, które są niezbędne dla jej rozwoju gospodarczego. Stąd, w ich przekonaniu, wynikało zaangażowanie polskiego rządu w umocnienie i uczynienie trwałym, stanu posiadania na tzw. „terenach odzyskanych” („territori ricuperati"). Przejawiać się ono miało nie tylko w ekspulsjach z tych terenów ich niemieckich mieszkańców ale w forsownej polityce zagospodarowania i zasiedlania tych ziem polską ludnością, która mimo zapewnień władz polskich i radzieckich o „ostatecznym” przebiegu zachodniej granicy wątpiła w jej trwałość. Braku poczucia stabilizacji i pewności, według włoskiego chargé d’affaires, w Warszawie, Raffaele Feretti'ego, było zjawiskiem powszechnym, odczuwanym przez polskich osiedleńców ${ }^{14}$.

Wątpliwości względem możności zagospodarowania przez Polskę tzw. Ziem Zachodnich oraz słuszności zapadłych w Poczdamie decyzji w tej kwestii, nie zgłaszał natomiast należący do WłPK ambasador Reale. Podkreślał on wielokrotnie w swych doniesieniach wysiłek polskich władz zmierzający do zagospodarowania tych terenów oraz „przywrócenia na ziemiach zachodnich kultury polskiej,

13 AMSZ, z. 15, t. 131, w. 14, S. Kot do MSZ, Zagadnienie polsko-niemieckie we Wtoszech, sprawozdanie nr 2, Rzym 11 I 1947; E. Buffo, La Questione polacca, Il Quotidiano 5 I 1947.

14 DDI, serie X, vol. VII, dok. 567, R. Feretti do C. Sforza, Warszawa 14 IV 1948; Por. Archivio del Ministero degli Affari Esteri (dalej: AMSZR), AP 1946-1950, Polonia, sygn. 13, R. Feretti do C. Sforza, 14 IV 1948. 
tępionej od wieków przez władze niemieckie (...)"15. Włoski dyplomata trafnie zauważał w swych raportach, iż obrona przez ZSRR polskiego stanu posiadania nad Odrą i Nysą Łużycką stanowi wytłumaczenie dla „prosowieckiej polityki” rządu polskiego, „do której odnosiła się z niechęcią większość społeczeństwa”. Stwierdzał, iż wspomniane nabytki są ważnym czynnikiem, legitymizującym władzę komunistów, który mógł ulec zniweczeniu w wypadku zmiany polityki radzieckiej na korzyść Niemiec. Wtedy to, jak donosił ambasador Reale, „wszystkie uzasadnienia polityki zagranicznej rządu staną się bezpodstawne i obecni przywódcy natrafiać będą na ogromne trudności, gdy dawać będą społeczeństwu gorzką pigułkę przyjaźni polsko-sowieckiej do połknięcia”. Reale zresztą nie wykluczał zmiany polityki Moskwy wobec Niemiec, łącząc ją z oświadczeniem Mołotowa z 10 lipca 1946 r. i wskazując, że wywołało ono „najwyższe zaniepokojenie w polskich kołach politycznych"16. Mimo, iż dyplomaci włoscy akredytowani w Polsce poświęcali wspomnianym problemom stosunkowo dużo miejsca w swych raportach, tłumacząc czynnikom kierowniczym Palazzo Chigi, racje polskiej polityki zagranicznej, dla której granica na Odrze i Nysie Łużyckiej stanowiła kwestię priorytetową i podkreślając wysiłek polskich władz i społeczeństwa wkładany w zagospodarowanie tego obszaru, nie odnosiło to większych efektów.

Kwestia niniejsza ze względu na przychylny Niemcom kierunek polityki włoskiej oraz obecne w szerokich kręgach społeczeństwa włoskiego sympatie dla narodu niemieckiego nie mogła liczyć (poza środowiskami związanymi z komunistami) na większe zainteresowanie oraz życzliwość. W sprawach polskich granic zachodnich większość establishmentu politycznego oraz pracowników włoskiego MSZ, tak jak chociażby poseł włoski w Pradze, orientowała się zresztą słabo, uważając ją z punktu widzenia włoskich interesów, za kwestię drugorzędną ${ }^{17}$.

Przegrana frontu ludowego w wyborach 18 kwietnia 1948, a w konsekwencji utworzenie rządu De Gasperiego (składającego się z chadeków, socjaldemokratów Saragata, liberałów i republikanów) oraz przyjęcie Włoch do NATO na wiosnę 1949 r., zinterpretowane przez „obóz socjalistyczny” jako złamanie traktatów pokojowych wywołało falę krytyki w Polskiej prasie oraz stało się jednym

15 E. Reale do MSZ w Rzymie, 21 VI 1946, [w:] E. Reale, Raporty. Polska 1945-1946, Warszawa 191, s. 205-206.

16 E. Reale do MSZ w Rzymie, 21 VI 1946, op. cit., s. 257-258. W swym oświadczeniu Mołotow wypowiedział się za zjednoczeniem Niemiec i utworzeniem w Berlinie rządu ogólnoniemieckiego, wypowiadając się przeciwko planom federalistycznym państw zachodnich. Szerzej na temat polityki ZSRR wobec kwestii niemieckiej. Zob. G.-H. Soutou, La guerre de Cinquante Ans. Les relations Est-Ouest 1943-1990, Paris 2001, s. 127.

17 AMSZ, z. 6, t. 1255, w. 82, chargé d'affaires a.i. w Pradze, R. Staniewcz do min. J. Olszewskiego, dyr. Dep. Polit. MSZ w Warszawie, Praga 10 I 1947. 
z powodów wyraźnego oziębienia się klimatu w powojennych relacjach polsko-włoskich. Do pogłębienia wzajemnych animozji przyczyniła się również polska nota protestacyjna (z 12 III 1952) skierowana do rządu włoskiego wyrażająca negatywne stanowisko władz polskich wobec uczestnictwa Rzymu w Pakcie Północnoatlantyckim. Na polsko-włoskich kontaktach zaciążyła także zacieśniająca się w latach 1950-1953 współpraca włosko-zachodnioniemiecka zarówno w kwestiach polityczno-wojskowych (w tym pozytywna postawa Włoch wobec Europejskiej Wspólnoty Obronnej) oraz wspólna wizja włosko-zachodnioniemiecka budowy Europy z udziałem RFN ${ }^{18}$.

Chociaż w połowie roku 1952 włoskie środowiska polityczne związane z lewicą oraz centrolewicą, a także opinia publiczna, zaczęły wykazywać coraz bardziej zdystansowany stosunek wobec remilitaryzacji RFN oraz z niepokojem śledziły słabe postępy denazyfikacji w tym kraju, radziecka ofensywa dyplomatyczna z lat 1952/1953 w kwestii niemieckiej (w tym nota Stalina z 10 III 1952) spowodowała zaostrzenie kursu rządów krajów zachodnich (w tym rządu włoskiego) wobec Moskwy i krajów zza żelaznej kurtyny, co nie mogło nie odbić się na kontaktach między Rzymem a Warszawą ${ }^{19}$. Czynniki te nie ułatwiały przybliżenia Włochom problemu polskiej granicy zachodniej, która z perspektywy Tybru, wydawała się kwestią drugorzędną i była postrzegana w aspekcie walki z cały blokiem wschodnim, a przede wszystkim z ZSRR.

Chadecki premier Alcide De Gasperi oraz związane z nim środowiska polityczne postrzegały (idąc śladami USA) w radzieckich propozycjach dotyczących zjednoczenia i neutralizacji Niemiec oraz ofensywie dyplomatycznej Moskwy, zagrożenie dla bloku zachodniego oraz ostrzegały sojuszników przed przedwczesnym podjęciem rokowań z tym mocarstwem. Polską granicę uznawały w ramach niniejszych poglądów jako „tymczasowy łup” bloku komunistycznego.

Wobec zacieśniających się relacji między Bonn a Rzymem²0, znamienna wydaje się wzmianka na temat polskiej granicy zachodniej w przemówieniu przedwy-

18 Odbiciem bliskich relacji między Włochami a RFN była wizyta De Gasperiego w Niemczech 21-25 IX 1952 r. De Gasperi popierał dozbrajanie RFN. Szerzej na temat współpracy między Włochami a RFN, zob. L. Berti, op. cit., s. 85-86.

19 Nota ZSRR z 10 III 1952 r. proponowała zjednoczenie Niemiec, które miały zachować neutralność, przy zachowaniu przebiegu granic na zasadzie uchwal podjętych w Poczdamie. Według oceny Zachodu propozycja niniejsza stanowiła pułapkę oraz próbę unicestwienia EWO. Zob. G.-H. Soutou, op. cit., s. 254-257. Niepokój wobec odradzającego się „totalitaryzmu niemieckiego” reprezentowała zarówno „La Stampa” jak i „Relazioni Internazionali”.

20 P. Guillen, op. cit., s. 283-284. O relacjach włosko-niemieckich w latach 1950-1952, zob. L. Berti, op. cit., s. 81-89. W latach 1950-1953 doszło do zacieśnienia oficjalnych stosunków politycznych między RFN i Włochami oraz wzmocnienia więzi gospodarczych. 
borczym premiera Alcide De Gasperi (w Mediolanie w dniu 26 kwietnia 1953 r. oraz w Turynie w dniu 1 maja tego roku). Nawiązując do rozwiązań przyjętych w tej sprawie przez trzy mocarstwa w Poczdamie, włoski polityk nadmienił, iż polskie nabytki terytorialne na zachodzie mają charakter tymczasowy, a ostateczny przebieg polskiej granicy zachodniej będzie przedmiotem traktatu pokojowego z Niemcami i zostanie zdecydowany w okresie późniejszym. Stwierdził on ponadto, iż trzy mocarstwa zgodziły się tylko tymczasowo, aby byłe tereny niemieckie na wschód od linii Odry-Nysy, były administrowane przez Polskę. „Mamy więc” - konkludował - „ważne terytorium, ważne z powodu kopalń i produkcji rolnej, oddane tymczasowo pod administrację polską. To wszystko jest zapisane w traktacie. Jednak w rzeczywistości zrusyfikowana Polska wzięła te tereny w posiadanie, tak jak Rosja wzięła w posiadanie Prusy Wschodnie, i nie chce z nich ustąpić: mamy tu do czynienia z granicą, która nie jest uznana. Mamy dwie części Niemiec: RFN z Bonn i NRD. Ta ostatnia zawarła układ uznający przejście tych terenów w polskie posiadanie; zaś rząd w Bonn odrzucił uznanie tego faktu. To jest niezaprzeczalnie trudny problem"21.

W atmosferze wzmożonego napięcia między Warszawą a Rzymem wypowiedź De Gasperiego oraz reperkusje, jakie wzbudziła ona w prasie polskiej, zostały uznane przez władze w Warszawie ,jako przejaw antypolskiej polityki rządu włoskiego” oraz „za akt nieprzyjazny wobec polskiego rządu” ${ }^{22}$.

Wyrazem pogarszających się relacji między dwoma krajami była rozmowa między ambasadorem Giovanni Guarnaschelli'm a wiceministrem Stefanem Wierbłowskim, na ten temat, który zarzucił De Gasperiemu ,jawne poparcie rewizjonizmu zachodnioniemieckiego". Broniąc stanowiska swego premiera, Guarnaschelli, zgodnie z instrukcją swej centrali, zapewnił Wierbłowskiego, że „De Gasperi nie miał żadnych intencji nieprzyjaznych wobec Polski i przypisywanie mu tak absurdalnych intencji jest całkowicie nieuzasadnione”23. Ambasador Włoch broniąc się, atakował swego rozmówcę, powołując się na przemówienie Józefa Cyrankiewicza z 1 -go maja. Polski premier w swym wystąpieniu przypisał bowiem De Gasperi'emu „zdradę włoskich interesów narodowych” ${ }^{24}$.

21 A. De Gasperi, Scritti e discorsi politici, [w:] Alcide de Gasperi e la stabilizzazione della Repubblica 1948-1954, red. S. Lorenzini e B. Taverni, Milano 1981, t. 2, s. 181-182.

22 AMSZ, ZD, t. 438, w. 36, szyfr. nr 384/SG, S. Wierbłowski do Frankowskiego, Warszawa 11 V 1947; Nowe wystapienie Watykanu, Trybuna Ludu 6 V 1953, nr 125 (1551). 11 V 1953 władze polskie połączyły sprawę wypowiedzi De Gasperiego dotyczącą granic ze sprawą otwartej $6 \mathrm{~V} 1953 \mathrm{r}$. wystawy „Mostra dell'Aldilă” i skierowały protest do rządu włoskiego.

23 AMSZR, AP 1950-1957, Polonia, sygn. 1209, G. B. Guarnaschelli do MSZ, Warszawa $20 \mathrm{~V} 1953$.

24 AMSZ, z. 8, t. 501, w. 38, notatka służbowa, dyr. Dep. II S. Gajewski, Warszawa 7 V 1953. 
Lodowatej atmosfery między Rzymem a Warszawą nie przełamał ani niekorzystny dla chadecji wynik wyborów we Włoszech (7 VI 1953), ani odejście w lecie 1953 r. Alcide De Gasperiego z włoskiej sceny politycznej. Tym bardziej, iż działania podjęte przez kolejne rządy związane z centrowym skrzydłem chadecji (Giuseppo Paelli, a potem Mario Scelby i Antonio Segni) ${ }^{25}$, zabiegające o amerykańskie poparcie dla sprawy powrotu Triestu do Włoch, nie były skłonne do zmiany kursu wobec krajów za żelazną kurtyną ${ }^{26}$.

Mimo wzrastających niesnasek oraz napięć w kontaktach między dwoma krajami, kończący na wiosnę 1955 roku swą misję w Polsce ambasador Guarnaschelli donosił w jednym ze swych raportów z Polski, poświęconemu granicy zachodniej, iż Polska jest „bardziej w wymiarze etnicznym niż geograficzno-terytorialnym, krajem jednolitym. Państwo polskie, ma zaś dzięki ekspulsjom $8 \mathrm{mln}$ Niemców i sprowadzeniu ludności polskiej z ZSRR, granice polityczne pokrywające się z granicami etnicznymi. Tereny na wschód od linii Odra-Nysa miały też być, w jego przekonaniu, „całkowicie spolonizowane, a próba zwrotu tych terenów Niemcom pociągnąć by musiała za sobą, przesiedlania na szeroką skalę, które mogłyby przybrać jeszcze bardziej nieludzki i katastrofalny charakter niż te z roku 1945”. Ambasador twierdził, powołując się na interesy sąsiadów RFN (a zwłaszcza Francji), a także Włoch, iż wzrost potęgi tego kraju oraz zarysowujące się perspektywy zjednoczenia Niemiec sprawiają, iż przynajmniej w jego ocenie, „faktor polski” przynajmniej częściowo, mógłby stać się przeciwwagą dla potęgi niemieckiej”. Stąd też, konkludował, „zarówno Włochy, jak i inne kraje atlantyckie winny być zainteresowane utrwaleniem granicy na Odrze i Nysie, a zjednoczenie Niemiec winno być uwarunkowane uznaniem przez RFN aktualnego przebiegu jej wschodniej granicy z Polską". Sugerował centrali, podjęcie działań politycznych, które miały prowadzić do rozluźnienia związków między Moskwą a Warszawą. Uznanie polskiej granicy zachodniej uważał za element zmniejszający uzależnienie polityczne Polski od ZSRR i wzmacniający sympatie większości Polaków wobec Zachodu. Utrzymywał także, iż uznanie polskiej granicy przyczyniłoby się do wzmocnienia integracji Europy w dalszej perspektywie również z udziałem Polski „silnej pod względem przemysłowym i terytorialnym względem jej sąsiadów wschodnich i zachodnich" ${ }^{27}$. Chociaż trudno odmówić ambasadoro-

25 G. Mammarella, L'Italia contemporanea 1943-2007, Bologna 2008, ss. 184, 202-230. Od 16 VII 1953 r. do VI 1958 r. rządy sprawowało 6 rządów, w który główną rolę odgrywała partia chadecka, rządząca ze zmiennym poparciem socjaldemokracji, republikanów, liberałów.

26 G. Mammarella, op. cit., s. 197-201.

27 AMSZR, Archivi di personalità, amb. Pasquale Jannelli, B1, fasc. 1, G. Guarnaschelli do Ministero degli Affari Esteri, Frontiera occidentale della Polonia, Warszawa 21 IV 1955. 
wi trafności zawartych w nim ocen, umiejętności perspektywicznego myślenia, a także sympatii dla Polaków, wydaje się, iż raport ten nie spotkał się z większym zainteresowaniem decydentów w Palazzo Chigi. Prowadziły one bowiem politykę lawirowania między swymi europejskimi sojusznikami z NATO, zacieśniając swe związki z Bonn i Waszyngtonem, które miały być według panujących we włoskim MSZ panaceum, na zrównoważenie hegemonistycznych ambicji Francji i Wielkiej Brytanii na kontynencie europejskim ${ }^{28}$.

Odwilż w stosunkach między Wschodem a Zachodem, związana ze śmiercią Stalina, XX Kongres KPZR oraz nawiązanie dialogu między ZSRR a USA (w połączeniu z popaździernikową odwilżą w Polsce) sprawiły, iż relacje na linii Warszawa - Rzym, aczkolwiek dalekie od wykorzystania potencjalnych możliwości, jak to było z w kontaktach PRL-u z krajami Europy Zachodniej, zaczęły rozwijać się w nieco lepszej atmosferze politycznej. Przyniosło to stopniową poprawę sytuacji, zwłaszcza w dziedzinie wymiany kulturalnej i naukowej ${ }^{29}$. Pewne nadzieje ze strony kierownictwa polskiego MSZ, na przełamanie stagnacji w relacjach z Włochami, pojawiły się w związku z objęciem urzędu prezydenckiego przez Giovaniego Gronchi'ego (29 IV 1955). Zwłaszcza, że polityk ten, związany z lewicowym nurtem chadecji, był zwolennikiem współpracy z socjalistami na gruncie włoskim oraz odłożenia integracji Niemiec z Europą Zachodnią i NATO do czasu zjednoczenia Niemiec ${ }^{30}$.

W tych okolicznościach znamienna, zdaje się być, prywatna wypowiedź udzielona przebywającemu w Rzymie polskiemu dziennikarzowi Juliuszowi Stroynowskiemu na jesieni 1957 r. Zapytany o osobistą opinię na temat granicy na Odrze i Nysie, Gronchi odpowiedział, że „jego zdaniem, a jest to chyba zdanie wszystkich realnie myślących polityków na świecie - granica ta ma charakter trwały i o zmianie jej praktycznie nie ma mowy”. Zagadnięty, w sprawie oficjalnego lub półoficjalnego uznania jej przez rząd włoski odparł, że formalnie sprawa ta musi być załatwiona ostatecznie w ramach traktatu pokojowego z Niemcami, a Włochy

28 Zob. E. di Nolfo, op. cit., s. 416-417.

29 AMSZ, z. 8, t. 836, w. 60, Raport polityczny Ambasady PRL w Rzymie za okres lipiec 1956-luty 1957, AMSZ, z. 8, t. 952, w. 69, Stosunki polsko-włoskiej, sprawozdanie polityczne amb. PRL w Rzymie, J. Druto, za pierwsze pótrocze 1 XII 1957-15 VI 1958, Rzym 26 VII 1958. Zob. E. di Nolfo, op. cit., s. 414.

30 Inną koncepcję wobec Niemiec lansował wtedy, sprawujący władzę (od 7 VII 1955 do 12 V 1957) rząd premiera M. Segni. W skład rządu poza chadecją wchodzili socjaldemokraci Saragata oraz liberałowie. Premier Segni był zwolennikiem szybkiej i ścisłej integracji RFN z NATO. Zob. A. Bedeschi-Magrini, Spunti revisionistici nella politica Estera di Giovanni Gronchi presidente della Repubblica, [w:] L'Italia e la politica di potenza in Europa (1950-60), red. E. di Nolfo, R. H. Rainero, B. Vigezzi, Milano 1992, s. 68. 
są małym krajem i muszą się liczyć z nastrojami swoich sojuszników”. Prezydent nadmienił również, że „wszelka tego rodzaju inicjatywa ze strony Włoch spotkałaby się z gwałtownym sprzeciwem pewnych kół w samych Włoszech oraz złą reakcją państw zachodnich a zwłaszcza RFN”. Gronchi nawiązał w cytowanej wyżej wypowiedzi do swej rozmowy z Konradem Adenauerem (z grudnia 1956), który w jego opinii „też nie myśli o zmianie granicy, ale ze względów wewnątrzkrajowych żaden rząd niemiecki nie może sobie na formalne uznanie granicy na Odrze i Nysie”. Włoski polityk podkreślił jednak, że chociaż Włochy nie mogą sobie pozwolić na żadną inicjatywę w tej sprawie, to on sam jest zainteresowany normalizacją stosunków między Polską a RFN. Radził ponadto, żeby „sprawę granicy traktować jako nieistniejącą aż do czasu traktatu pokojowego z Niemcami”. Jak podkreślał, „w tej kwestii liczył na duże postępy”, gdyż jak utrzymywał, „w najbliższym czasie miało dojść do zbliżenia między obydwoma państwami niemieckimi" ${ }^{31}$.

Chadeckie rządy Adone Zoli, a zwłaszcza Amintore Fanfani oraz Antonio Segni, mimo pojawiających się we włoskich kołach politycznych prób zmierzających w kierunku uzyskania większej niezależności w decyzjach politycznych przez kraje NATO (neoatlantyzm związany z prezydentem Gronchi i chadecką lewicą) nie były skłonne do popierania koncepcji rozbrojeniowych lansowanych przez Warszawę w latach 1958-1959, upatrując w procesie odprężenia między Waszyngtonem a Moskwą niebezpieczeństwa dojścia do porozumienia dwóch mocarstw ponad Europą oraz ograniczenia amerykańskiej obecności militarnej i gospodarczej. Stąd wynikała zgoda rządu włoskiego na umieszczenie we Włoszech wyrzutni rakiet z głowicami atomowymi (Jupiter) wyrażona już w roku 1958. Polityka włoska niezainteresowana $\mathrm{w}$ tym okresie sprawą rozbrojenie oraz polskimi planami dotyczącymi détente dążyła do aktywizacji na Bliskim Wschodzie oraz Afryce. W Europie natomiast zmierzała do budowy zwartego bloku państw zachodnich, czego wyrazem stało się utworzenie Wspólnego Rynku Europejskiego (uwieńczone przyjęciem 25 III 1957 traktatu w Rzymie), zdolnego włączenia się w dialog USA-ZSRR. W praktyce przekładało się to na utrzymanie tempa zbrojeń i uniemożliwienie pertraktacji rozbrojeniowych między Moskwą a Waszyngtonem, bez udziału Europy.

Z powyższych pryncypiów wynikała niechęć rządów chadeckich w angażowanie się w jakiekolwiek inicjatywy dla „odprężenia i normalizacji”, zwłaszcza jeśli miało to prowadzić do rozwiązań kosztem ważnego sojusznika Rzymu,

31 AMSZ, z. 8 w. 61, t. 838, Sprawozdanie [J. Stroynowskiego] z rozmowy z prezydentem Gronchi, przeprowadzonej dnia 12 X 1957 r. w mieszkaniu prywatnym prezydenta. Rozmowy Adenauer-Gronchi miały miejsce w grudniu 1956 r. Zob. G. Mammarella, op. cit., s. 248. 
tj. RFN ${ }^{32}$. Tym bardziej, iż w szeregach chadeckich kół rządowych, dominowało zrazu przekonanie o bezcelowości podejmowania przez Włochy jakichś kroków w dziedzinie polityki światowej, nie dotyczącej bezpośrednio Włoch ${ }^{33}$. Toteż mimo wysiłków nie udało się nawiązać skromnego nawet dialogu z rządem włoskim na temat tzw. planu Rapackiego, w którym włoska prasa prawicowa postrzegała środek zmierzający do utrwalenia terytorialnego stanu posiadania przez komunistyczną Polskę. Plan Rapackiego został podczas debaty we włoskim parlamencie w dniu 5 lutego 1958 r., przez włoskiego ministra spraw zagranicznych i wicepremiera Giuseppe Pellę w rządzie Zoli, odrzucony ${ }^{34}$. Pella stwierdził, że z wojskowego punktu widzenia nie ma on dużego znaczenia praktycznego, natomiast $\mathrm{w}$ aspekcie politycznym zmierza on do stopniowego osłabienia Europy w oparciu o podział Niemiec, a więc do rozbicia NATO ${ }^{35}$. Zgodnie ze stanowiskiem włoskiego rządu, taktyka kół rządowych w kwestii planu Rapackiego ograniczać się miała do „wysłuchania uwag bez ustosunkowania się do argumentacji strony polskiej”36. Mimo stopniowej zmiany taktyki rządu włoskiego wobec planu Rapackiego i przyjęcia w następnych miesiącach bardziej wyważonego stanowiska, nie uległo ono zasadniczej zmianie, sprowadzając się do obietnic „uważnego zbadania” planu. Niniejsza taktyka wynikała z obaw pozostawienia WłPK monopolu w sprawie odprężenia w obliczu zbliżających się w maju 1958 r. wyborów parlamentarnych we Włoszech i uczynienia zeń instrumentu propagandowego ${ }^{37}$.

Fachowy aparat Palazzo Chigi, jak się wydaje, nie bez udziału, nowego ambasadora Włoch w Warszawie, Pasquale Jannelli'ego, uznał ostatecznie plan Ra-

32 AMSZ, z. 8, w. 69, t. 953, notatka W. Domagaty, radcy ambasady PRL $w$ Rzymie na temat debaty parlamentarnej nad wtoska polityka zagraniczna, Rzym 18 II 1958. Czynniki rządowe wypowiadały się za uczynienia ze sprawy zjednoczenia Niemiec kwestii centralnej w negocjacjach odprężeniowych Wschód-Zachód. Min. Pella był przeciwnikiem koncepcji neutralizacji zjednoczonych Niemiec.

33 AMSZ, ZD, w. 60, t. 844, szyfr. nr 408, amb. J. Druto do H. Bireckiego, Rzym 11 I 1958; szyfr. [bez nr] J. Druto do tegoż, Rzym 14 I 1959. Według kół rządzących, w relacji Druto, propozycje polskie uważano „za regionalistyczną i zbyt ograniczoną i stąd nie mogą one rozstrzygnąć zagadnienia: wojna lub pokój. Ponadto sam plan utrudniałby rozwiązanie problemu niemieckiego".

34 II legislatura, Atti Parlamentari, disussioni del 5 febbraio 1958, AMSZ, z. 8, w. 69, t. 953, notatka W. Domagaty, radcy ambasady PRL $w$ Rzymie na temat debaty parlamentarnej nad wtoska. polityka zagraniczna, Rzym 18 II 1958.

35 AMSZ, ZD, w. 60, t. 844, szyfr. nr 1655, amb. J. Druto do H. Bireckiego, Rzym 6 II 1958.

36 AMSZ, J. Druto do H. Bireckiego, dyr. Dep. I MSZ, notatka na temat stosunków polsko-wtoskich za I pótrocze 1959 r., Rzym 8 IX 1959; ibidem, z. 8, w. 69, t. 953, notatka W. Domagaty, radcy ambasady PRL $w$ Rzymie na temat debaty parlamentarnej nad wtoska polityka zagraniczna, Rzym 18 II 1958.

37 AMSZ, ZD, w. 60, t. 844, szyfr. nr 4320, amb. J. Druto do P. Ogrodzińskiego, Rzym 9 IV 1958. 
packiego za „wycinkowy”, „drugorzędny”, „nie mający szans na realizację, dopóki nie zostaną stworzone przesłanki dla wzajemnego zaufania między obydwoma blokami”"38. Swych wątpliwości względem szans na jego realizację, włoski dyplomata nie krył w rozmowie z ministrem Rapackim. Opisując rozmowę z szefem polskiego MSZ-u w raporcie dla swego kierownictwa, uznał, iż „plan może być polską inicjatywą” (co według niego, nie miało większego znaczenia) ale jednocześnie podkreślał, że „stanowi on część integralną „manewru dyplomatycznego $\mathrm{i}$ „propagandowej techniki sowieckiej ${ }^{39}$.

Jannelli w opracowaniu skierowanym do prezydenta Gronchiego w listopadzie 1958 roku, złagodził nieco swoje poprzednie stanowisko, mając być może na względzie poglądy adresata ${ }^{40}$. Tym razem włoski dyplomata uznał, plan Rapackiego za „pierwotnie” i „autentycznie” polski. Świadczyć o tym miała „uporczywość Polski w jego prezentacji” oraz „kurczowe trzymanie się idei odprężenia między dwoma blokami, które, „miało zapobiec nieprzyjemnym niespodziankom ze strony ZSRR i RFN oraz ustabilizować polskie granice”. Kwestię granicy polsko-niemieckiej, której zachowanie stanowiło priorytet dla Polski i całego obozu komunistycznego, włoski ambasador uważał za kwestię kluczową nie tylko dla Europy środkowo-wschodniej ale również dla przyszłej polityki Zachodu wobec państw satelickich bloku wschodniego. ${ }^{41}$

Kołami, które popierały plan Rapackiego była część socjalistów z lewego skrzydła WłPS oraz komuniści, lansujący hasło dezatomizacji Włoch w ramach haseł zgłaszanych przez Ruch Obrońców Pokoju ${ }^{42}$. Socjaliści włoscy byli zwolennikami zjednoczenia i neutralizacji Niemiec oraz popierali plan Rapackiego, jako pierwszy

38 AMSZ, ZD, w. 60, t. 844, szyfr. nr 3271, amb. J. Druto do P. Ogrodzińskiego, Rzym 17 III 1958; amb. Janneli nie krył swej opinii na temat planu Rapackiego w rozmowie z ambasadorem PRL w Rzymie, J. Druto.

39 AMSZR, Archivi di personalità, amb. Pasquale Jannelli, B. 1, fasc. 1, amb. G. Guarnaschelli do MSZ w Rzymie, La Polonia e il „Piano di Rapacki”, Warszawa 10 II 1958. Por. AMSZ, ZD, w. 60, t, 844., szyfr. nr 3924, J. Druto do P. Ogrodzińskiego, Rzym 31 III 1958.

40 Wywodzący się z lewicowej frakcji chadecji, Gronchi wypowiadał się za współpracą z socjalistami oraz był zwolennikiem rewizji NATO. Zob. G. Mammarella, op. cit., s. 212-215.

${ }^{41}$ AMSZR, Archivi di personalità, amb. Pasquale Jannelli, B. 1, fasc. 2, amb. P. Jannelli do prez. Gronchi, Rzym 24 XI 1958.

42 AMSZ, z. 23, w. 14, t. 163, notatka M. Naszkowskiego w/s planu Rapackiego, Warszawa 17 I 1958. Ze względów taktycznych polski MSZ radził działaczom lewego skrzydła WłPS nie łączyć planów dezatomizacji Włoch z planem Rapackiego. Niniejsza opinia została zaaprobowana przez działaczy tejże partii Luzzato i Gaggero. WłPK zajęła wobec tego problemu analogiczną postawę. W trakcie rozmowy z amb. Druto, Togliatti stwierdził, iż zgadza się ze stanowiskiem Warszawy, a sprawę dezatomizacji Włoch uważa za wewnętrzno-propagandową. Zob. AMSZ, ZD, w. 60, t. 844, szyfr. nr 1571, J. Druto do A. Rapackiego, Rzym 5 II 1958 r. 
krok w tym kierunku ${ }^{43}$. Natomiast chadecja włoska przeciwstawiała się planowi Rapackiego twierdząc, że żadne częściowe porozumienie nie ma sensu w aktualnej sytuacji, dopóki nie nastąpi porozumienie ZSRR i USA. W przekonaniu liderów chadecji plan Rapackiego utrwalał podział Niemiec, a ich dezatomizacja miała osłabić Zachód, przy zachowaniu przewagi Wschodu w broni konwencjonalnej ${ }^{44}$.

Sprawę planu Rapackiego polska dyplomacja próbowała podnieść na gruncie włoskim, po raz kolejny, przy okazji wizyty w Rzymie (na jesieni 1958 r.) posła „Znaku”, Stanisława Stommy posiadającego kontakty ze środowiskiem chadeckim. Na prośbę ambasady PRL w Rzymie Stomma rozmawiał o planie z włoskim z wiceministrem spraw zagranicznych, Guglieimo Folchi'm, który powtarzając wcześniejsze zastrzeżenia Palazzo Chigi wobec planu w złagodzonej formie, podkreślił, że „plan właściwie nie dotyczy Włoch”־5. Środowiska chadeckiej lewicy związane z rządem Fanfaniego, który po wyborach w maju 1958 sformułował rząd składający się z chadeków i socjaldemokratów Saragata, sygnalizowały natomiast Stommie możliwość radykalnej poprawy w stosunkach polsko-włoskich w związku z bardziej autonomiczną wobec USA linią polityki rządu Fanfaniego ${ }^{46}$. Wyrazem wzrastającego zainteresowania kontaktami (zwłaszcza gospodarczymi) z Warszawą miała być wizyta związanego z Fanfani'm i lewicą chadecką a zarazem szefa państwowego koncernu energetycznego, (Enze Nazionale Idrocarburi), Enrico Mattei, w Warszawie, zrealizowana „za wiedzą i zgodą” premiera ${ }^{47}$. Otwarciu na Wschód sprzyjać miała polityka Fanfaniego „otwarcia na lewicę” (tj. socjalistów z WłPS). Dymisja rządu Fanfaniego (26 I 1959) spowodowana zaostrzającą się walką w łonie Chrześcijańskiej Demokracji oraz socjalistów Saragata w powiązaniu $\mathrm{z}$ atakami na premiera w obliczu jego aktywnej polityki wobec Bliskiego Wschodu ze strony USA ${ }^{48}$, odsunęly kwestie dotyczące relacji z Polską

43 AMSZ, z. 8, t. 1052, w. 75, notatka amb. J. Druto, Wtochy a problem niemiecki a spotkanie Wschód-Zachód, Rzym 26 III 1959.

44 AMSZ, ZD, w. 60, t, 844., szyfr. nr 2281, J. Druto do H. Bireckiego Rzym 21 II 1958. Takie stanowisko zajmowali liderzy chadecji w rozmowie z polskimi dyplomatami, m.in.: Pella, Helfer, Facchine; ibidem, szyfr. nr 4320, J. Druto do M. Naszkowskiego, Rzym 9 IV 1958.

45 AMSZ, ZD, w. 60, t. 844, szyfr. nr 13899, M. Wielgosz do P. Ogrodzińskiego, Rzym 4 XI 1958.

46 AMSZ, ZD, w. 60, t. 844, szyfr. nr 14281, J. Druto do P. Ogrodzińskiego, Rzym 11 XI 1958. Takie wnioski wyciągnął Stomma z rozmów z G. La Pira, G. Folchim, E. Malfattim.

47 AMSZ, ZD, w. 60, t. 844, szyfr. nr 14626, J. Druto do P. Ogrodzińskiego, Rzym 19 XI 1958; AMSZ, ZD, z. 8, t. 963, w. 63, notatka St. Kłosa na temat wizyty w Polsce p. Enrico Mattei, szefa ENI, Rzym 18 II 1958; AMSZ, ZD, szyfr. nr 13679, P. Ogrodziński do J. Druto, Warszawa, 17 XI 1958, Relacja z pobytu Mattei w Warszawie; szyfr. nr 14626, J. Druto do P. Ogrodzińskiego, 20 XI 1958.

48 J. A. Gierowski, op. cit., s. 656. 
i blokiem wschodnim na pewien okres. Polityki zbliżenia ze Wschodem nie podją prawicowy rząd Segniego, który storpedował przygotowania do wizyty prezydenta Gronchiego w Polsce, która miała utorować drogę do dialogu politycznego między Rzymem a Warszawą ${ }^{49}$.

Problem polskiej granicy zachodniej oraz polskie plany dotyczących rozbrojenia niecieszące się większym zainteresowaniem włoskich kół politycznych zniknęły na długi okres z włoskiej sceny politycznej.

49 AMSZ, ZD, w. 64, t. 949, szyfr. [bez nr], M. Naszkowski do amb. A. Willmanna, Warszawa 9 XII 1959; AMSZ, ZD, szyfr. nr 15163, A. Willmann do M. Naszkowskiego, Rzym 16 XII 1959; AMSZ, ZD, szyfr. nr 15599, A. Willmann do M. Naszkowskiego, Rzym 29 XII 1959. 